CELLA, José Renato Gaziero; ZOLET, Lucas Augusto da Silva; COPETTI, Rafael. Processo político como construção democrática: uma discussão acerca dos processos eleitorais formados por apenas uma candidatura. Revista Eletrônica Direito e Política, Programa de Pós-Graduação Stricto Sensu em Ciência Jurídica da UNIVALI, Itajaí, v.15, n.3, 30 quadrimestre de 2020. Disponível em: www.univali.br/direitoepolitica - ISSN 1980-7791

\title{
PROCESSO POLÍTICO COMO CONSTRUÇÃO DEMOCRÁTICA: UMA DISCUSSÃO ACERCA DOS PROCESSOS ELEITORAIS FORMADOS POR APENAS UMA CANDIDATURA
}

\author{
POLITICAL PROCESS AS DEMOCRATIC CONSTRUCTION: A DISCUSSION ABOUT
}

THE ELECTORAL PROCESS FORMED ONLY ONE APPLICATION

\author{
José Renato Gaziero Cella ${ }^{1}$ \\ Lucas Augusto da Silva Zolet ${ }^{2}$ \\ Rafael Copetti ${ }^{3}$
}

\section{RESUMO}

Este trabalho, guiado por estudo de caso que orienta a utilização de método hipotético-dedutivo, propõe o estudo acerca do problema dos processos políticos eleitorais formados por apenas uma candidatura, notadamente no Brasil, sobretudo fazendo uma contraposição com o dever de respeito aos pressupostos dos processos políticos democráticos como hipótese alinhada à Democracia. Defende-se que estes modelos singulares não contribuem para um possível desenvolvimento dos cenários políticos sustentáveis. A hegemonia de pequenos grupos e a ausência de uma perspectiva real de participação nas tomadas de decisões é um perigoso espaço para abuso do poder político. A relevância deste trabalho, portanto, funda-se no pressuposto de que as práticas democráticas não podem ser baseadas em modelos de suposto consenso, mas no reconhecimento do elemento do desacordo coletivo como circunstância política de diálogo democrático acerca das principais questões da vida social. O desacordo como ideal da Democracia permite o efetivo direito de escolha, projeta a cidadania e o desenvolvimento das liberdades como defesa das diferentes composições ideológicas da comunidade.

PALAVRAS-CHAVE: Democracia; Desacordo; Processo Político Democrático; Robert Dahl.

\footnotetext{
1 Doutor em Filosofia e Teoria do Direito pela UFSC. Mestre em Direito do Estado pela UFPR. Docente do Programa de Pós-Graduação Stricto Sensu em Direito da IMED. E-mail: cella@cella.com.br

${ }^{2}$ Mestre em Direito - Mestrado em Direito, Democracia e Sustentabilidade, IMED. Especialista em Direito Público, FDDJ. Docente do Curso de Direito, FABE/Marau. E-mail: lucas.zolet@fabemarau.pro.br

${ }^{3}$ Doutorando em Direito pela UFSC.Especialista em Direito Público pela IMED/ESMAFE. Docente do curso de Direito na FABE Marau. Servidor Público Federal TRE-RS. E-mail: rafaelcopetti@yahoo.com.br
} 
CELLA, José Renato Gaziero; ZOLET, Lucas Augusto da Silva; COPETTI, Rafael. Processo político como construção democrática: uma discussão acerca dos processos eleitorais formados por apenas uma candidatura. Revista Eletrônica Direito e Política, Programa de Pós-Graduação Stricto Sensu em Ciência Jurídica da UNIVALI, Itajaí, v.15, n.3, 30 quadrimestre de 2020. Disponível em: www.univali.br/direitoepolitica - ISSN 1980-7791

\section{ABSTRACT}

This work, guided by case study that guides the use of hypothetical-deductive method, proposes the study of the problem of electoral political processes formed by only one application, notably in Brazil, especially making a contrast with the duty to respect the assumptions of democratic political processes as chance aligned with Democracy. It is argued these unique models will not contribute to the possible development of sustainable policy scenarios. The hegemony of small groups and the absence of a real prospect of participation in decision-making is a dangerous space for abuse of political power. The relevance of this work, therefore, is based on the assumption that the democratic practices cannot be based on a supposed consensus models, but in recognition of the element of collective disagreement as democratic dialogue of political circumstances on the main issues of social life. Disagreement as ideal of Democracy allows the effective right to choose, designs citizenship and the development of freedoms and defense of the different ideological compositions of the community.

KEYWORDS: Democracy; Disagreement; Democratic Political Processes; Robert Dahl.

\section{INTRODUÇÃO}

O objetivo geral desta pesquisa, na qual se analisa criticamente o caso dos processos eleitorais havidos no município de Mato Queimado, RS, é introduzir o problema dos processos políticos eleitorais formados por apenas uma candidatura, sobretudo no contexto do Estado Democrático de Direito. Apresenta-se, para tanto, uma abordagem circunscrita e pautada principalmente nas discussões doutrinárias relativas aos pressupostos políticos da Democracia.

Esta revisão bibliográfica, produzida pelo método hipotético-dedutivo, parte da hipótese de que os modelos políticos singulares não respeitam efetivamente os pressupostos mais básicos da Democracia, por exemplo, da ampla discussão pública, da legitimação pelo desacordo, da consideração plural de interesses e da existência de oposição política.

Nesse sentido, o objeto do presente estudo está inserido nas categorias do Direito e da Democracia, sobretudo porque os temas ora tratados estão relacionados aos fundamentos do Estado Democrático de Direito, bem como ao desenvolvimento da Democracia em sua relação com os paradigmas da sociedade contemporânea. 
CELLA, José Renato Gaziero; ZOLET, Lucas Augusto da Silva; COPETTI, Rafael. Processo político como construção democrática: uma discussão acerca dos processos eleitorais formados por apenas uma candidatura. Revista Eletrônica Direito e Política, Programa de Pós-Graduação Stricto Sensu em Ciência Jurídica da UNIVALI, Itajaí, v.15, n.3, 30 quadrimestre de 2020. Disponível em: www.univali.br/direitoepolitica - ISSN 1980-7791

Os pressupostos teóricos trazidos nesta pesquisa são relevantes porque fazem parte dos aspectos constitutivos dos processos políticos democráticos. A partir da discussão das suas características fundamentais, afirma-se que os modelos singulares de processo político, aqueles formados por apenas uma candidatura, não respeitam as concepções vinculadas aos fundamentos do Estado Democrático.

A pesquisa está estruturada em duas partes compostas por objetivos específicos. $\mathrm{Na}$ primeira será apresentada a relação entre o problema de pesquisa com as características fundamentais do processo político democrático defendidas por Robert Dahl. Ainda nesta parte serão discutidos os aspectos básicos da Poliarquia e sua incompatibilidade com os modelos singulares de representação política.

$\mathrm{Na}$ segunda parte serão considerados os principais fundamentos do processo político democrático, sobretudo, os aspectos relacionados ao complexo da pluralidade de interesses e o desacordo público como elementos essenciais da construção política democrática de determinada sociedade.

A partir dessa linha de pensamento, justifica-se a presente pesquisa por meio do estudo das características fundamentais dos processos políticos, principalmente como pressupostos necessários a fortalecer uma compreensão exata da legitimidade política e das condições para o exercício democrático da gestão pública.

Deste modo, a interpretação e identificação dos obstáculos relativos ao desenvolvimento efetivo da Democracia é um elemento fundamental para conferir relevância aos pressupostos democráticos dos processos políticos, por exemplo, a consideração da dimensão do debate público e do antagonismo de interesses como conceitos indispensáveis aos processos eleitorais.

Nota-se que a relevância do trabalho está fundada no argumento de que modelos políticos singulares, no que se refere à fragilização de pressupostos democráticos e na medida em que alcancem maiores espaços e dimensões político-estruturais, podem interferir inclusive no desenvolvimento de cenários politicamente equilibrados. 
CELLA, José Renato Gaziero; ZOLET, Lucas Augusto da Silva; COPETTI, Rafael. Processo político como construção democrática: uma discussão acerca dos processos eleitorais formados por apenas uma candidatura. Revista Eletrônica Direito e Política, Programa de Pós-Graduação Stricto Sensu em Ciência Jurídica da UNIVALI, Itajaí, v.15, n.3, 30 quadrimestre de 2020. Disponível em: www.univali.br/direitoepolitica - ISSN 1980-7791

Os processos políticos eleitorais estão inseridos no centro dos regimes democráticos, dado que fazem parte da etapa inicial das deliberações coletivas, bem como correspondem aos próprios pilares de um futuro governo. Se já na origem alguns pressupostos democráticos não são devidamente respeitados, então existem boas chances de que, no decorrer do exercício do governo, menor sejam os níveis de diálogo democrático, consideração plural de interesses e possibilidade de vigilância e fiscalização das ações políticas.

A desconsideração da importância dessas características pressupõe, também, que governos formados por modelos de processos políticos singulares não estão efetivamente alinhados com os pressupostos mais básicos da Democracia. Logo, governos vinculados ao modelo político singular podem significar um regime de Democracia restrita, em que a cidadania pode ser substancialmente limitada.

Todos esses argumentos são responsáveis por sustentar que a Democracia não está fundada unicamente em suposto consenso, mas também nos desacordos sobre as principais questões da vida social. Os desacordos refletem um processo político real desde a origem, em que a principal preocupação está formatada no diálogo democrático como um elemento determinante para fins de novas posições dos direitos e políticas públicas.

Assim, ao desenvolver uma relação entre os principais temas apresentados, propõe-se uma pesquisa bibliográfica acerca dos problemas constitutivos da Democracia.

\section{O PROBLema dOS MODELOS POLÍticos Singulares E AS CARACTERÍSTICAS FUNDAMENTAIS DOS PROCESSOS POLÍtICOS DEMOCRÁTICOS}

A busca pelo consenso dos diferentes interesses públicos em uma Democracia ${ }^{4}$ é uma tarefa extremamente difícil. A complexidade contemporânea das relações

\footnotetext{
${ }^{4}$ Segundo Alexy a Democracia pode ser compreendida como um procedimento de decisão e como um procedimento de argumentação. O procedimento da decisão, como princípio da maioria, é a dimensão real da Democracia. A argumentação, como debate público, trata-se do lado ideal da Democracia. Nada obstante, para Dahl o regime democrático é um modelo superior a outros modos de governo em pelo menos três pontos. Primeiro, na capacidade de promover a liberdade, segundo, na condição de promoção do desenvolvimento humano e, terceiro, é o mais efetivo processo para garantir que os indivíduos possam proteger e promover os interesses e bens que
} 
CELLA, José Renato Gaziero; ZOLET, Lucas Augusto da Silva; COPETTI, Rafael. Processo político como construção democrática: uma discussão acerca dos processos eleitorais formados por apenas uma candidatura. Revista Eletrônica Direito e Política, Programa de Pós-Graduação Stricto Sensu em Ciência Jurídica da UNIVALI, Itajaí, v.15, n.3, 30 quadrimestre de 2020. Disponível em: www.univali.br/direitoepolitica - ISSN 1980-7791

sociais e as infindáveis características que separam os indivíduos favorece a ideia de que a vida pública avança em desacordo. No meio político partidário as inconformidades entre consenso e dissenso acerca da vida social se mostram ainda mais expressivos. A ideia de gestão política de um Município, Estado ou País engloba também o problema de administrar uma grande variedade de interesses conflitantes entre si.

Nesse sentido, não é possível defender a existência de sistemas políticos representativos fundados em pleno consenso. Embora a ideia do acordo político traga implicitamente o argumento da governabilidade, a plena concordância de opiniões acerca da forma do exercício do poder de governar é um ideal irrealizável na sociedade contemporânea.

Nota-se que um consenso maquiado pode permitir que grupos políticos minoritários fragilizem as discussões públicas, a cidadania, a consideração da pluralidade de interesses, o próprio diálogo democrático, bem como as decisões públicas que interessam a uma coletividade. Questiona-se, portanto, o pressuposto problemático de que os modelos políticos singulares não concebam uma hipótese democrática de processo político.

É por evidente que as eleições consensuais não têm sido a regra no sistema político e eleitoral do Brasil. Essa questão pode ser vista, especialmente, nas eleições gerais (em que os eleitores devem escolher seus representantes nas Assembleias Legislativas, Câmara dos Deputados, Senado Federal, além dos respectivos Governadores e o Presidente da República, e seus substitutos). Nessas hipóteses, geralmente, o número de agremiações partidárias e interesses diversos contribuem para o antagonismo ideológico e para o aumento de pessoas disputando o acesso aos cargos eletivos.

Por outro lado, o problema dos modelos políticos singulares apresenta uma realidade que não deve ser desconsiderada, notadamente nas eleições municipais. No ano de 2012, por exemplo, conforme dados divulgados pelo 
CELLA, José Renato Gaziero; ZOLET, Lucas Augusto da Silva; COPETTI, Rafael. Processo político como construção democrática: uma discussão acerca dos processos eleitorais formados por apenas uma candidatura. Revista Eletrônica Direito e Política, Programa de Pós-Graduação Stricto Sensu em Ciência Jurídica da UNIVALI, Itajaí, v.15, n.3, 30 quadrimestre de 2020. Disponível em: www.univali.br/direitoepolitica - ISSN 1980-7791

Tribunal Superior Eleitoral, 106 Municípios brasileiros tiveram apenas uma opção de candidato na disputa para a executivo municipal. ${ }^{5}$

Nesses casos, para que o candidato seja considerado eleito, na hipótese de um Município possuir menos de 200.000 (duzentos mil) eleitores, é preciso apenas um voto válido ${ }^{6}$. Votos brancos e nulos, portanto, não são contabilizados, são desprezados no momento da totalização.

Considerando o disposto no parágrafo segundo do artigo $3^{\circ}$ da Lei Federal $n^{\circ}$ 9.504, de 30 de setembro de $1997^{7}$, para os Municípios com número de eleitores superior ao quantitativo mencionado é necessário obter $50 \%$ dos votos válidos. Assim, caso o candidato tenha apenas um voto, igualmente estará eleito porque terá obtido a totalidade dos votos ( $50 \%$ dos votos válidos seria 0,5 ; como não há possibilidade de meio voto, deve-se arredondar ao número inteiro imediatamente superior, no caso, um, justamente o número de votos obtido), sendo desnecessária a realização de segundo turno.

Exemplo interessante vem ocorrendo no Município de Mato Queimado, no Rio Grande do Sul. Emancipado no ano de 1996, realizou a primeira eleição municipal no pleito do ano 2000 e nunca teve mais de um candidato para o cargo de prefeito. Em entrevista, o ex-prefeito Orcelei Dalla Barba (gestão 2008-2012) afirmou que:

Antes das eleições as lideranças políticas dos quatro partidos existentes na cidade (PT, PMDB, PTB e PP) se reúnem e decidem quem vai governar o município [asseverando que] esta já é a quarta eleição na forma consensual, onde não há

\footnotetext{
5 AGÊNCIA BRASIL. Em 106 municípios, apenas um candidato disputará a prefeitura. Brasília: Empresa Brasil de Comunicação, 2012b. Disponível em: <http://memoria.ebc.com.br/agenciabrasil/noticia/2012-07-26/em-106-municipios-apenas-umcandidato-disputara-prefeitura>. Acesso em: 22 abril 2015.

6 Segundo o artigo $3^{\circ}$ da Lei Federal no 9.504, de 30 de setembro de 1997, "Será considerado eleito Prefeito o candidato que obtiver a maioria dos votos, não computados os em branco e os nulos". BRASIL. Lei no 9.504 (1997). Lei no 9.504. Estabelece normas para as eleições. Brasília, DF: Presidência da República, $1997 . \quad$ Disponível em: <http://www.planalto.gov.br/ccivil_03/leis/I9504.html>. Acesso em: 28 abril 2015.

7 Segundo o artigo $3^{\circ}$ da Lei Federal no 9.504, de 30 de setembro de 1997, "Será considerado eleito Prefeito o candidato que obtiver a maioria dos votos, não computados os em branco e os nulos". BRASIL. Lei no 9.504 (1997). Lei no 9.504. Estabelece normas para as eleições. Brasília, DF: Presidência da República, $1997 . \quad$ Disponível em:
} <http://www.planalto.gov.br/ccivil_03/leis/19504.html>. Acesso em: 28 abril 2015. 
CELLA, José Renato Gaziero; ZOLET, Lucas Augusto da Silva; COPETTI, Rafael. Processo político como construção democrática: uma discussão acerca dos processos eleitorais formados por apenas uma candidatura. Revista Eletrônica Direito e Política, Programa de Pós-Graduação Stricto Sensu em Ciência Jurídica da UNIVALI, Itajaí, v.15, n.3, 30 quadrimestre de 2020. Disponível em: www.univali.br/direitoepolitica - ISSN 1980-7791

rivalidade política e onde há respeito mútuo entre os partidos. ${ }^{8}$

Ademais, no referido Município o consenso não se restringe à escolha do representante no executivo. Igualmente é realizado acordo para a escolha dos candidatos às nove vagas da Câmara Municipal de Vereadores, não tendo havido oposição em nenhum dos pleitos realizados. Conforme a reportagem da Agência Brasil "[...] nunca houve qualquer candidato de oposição na disputa pelas nove vagas da Câmara Municipal. Os vereadores sempre disputam sob uma coligação única, que envolve os quatro partidos". ${ }^{9}$

Importa referir que a forma de eleição dos candidatos ao cargo de vereador não é a mesma da demonstrada para o cargo de Prefeito. Diferentemente da eleição para os cargos do Poder Executivo ou para o Senado Federal, que se baseiam no sistema majoritário, a legislação eleitoral brasileira adota na eleição para as Câmaras Municipais, Assembleias Legislativas e Câmara dos Deputados o sistema de representação proporcional com lista aberta, consoante artigo 84 do Código Eleitoral ou Lei Federal no $4.737^{10}$. Ou seja, os eleitores votam em nomes (lista) previamente definidos pelos partidos políticos, sendo que a ordem final de eleição deve estar em consonância com o número de votos obtidos por cada um dos concorrentes.

No sistema proporcional o elemento mais relevante não é exatamente o candidato, mas sim o partido político, sendo que "Nas eleições, cada partido apresenta uma lista e candidatos. O eleitor vota em uma dessas listas - alguns

\footnotetext{
8 AGÊNCIA BRASIL. Município do noroeste gaúcho nunca teve disputa eleitoral para prefeitura. Brasília: Empresa Brasil de Comunicação, 2012a. Disponível em: <http://memoria.ebc.com.br/agenciabrasil/noticia/2012-07-26/municipio-do-noroeste-gauchonunca-teve-disputa-eleitoral-para-prefeitura>. Acesso em: 22 abril 2015.
}

9 AGÊNCIA BRASIL. Município do noroeste gaúcho nunca teve disputa eleitoral para prefeitura. Brasília: Empresa Brasil de Comunicação, 2012a. Disponível em: <http://memoria.ebc.com.br/agenciabrasil/noticia/2012-07-26/municipio-do-noroeste-gauchonunca-teve-disputa-eleitoral-para-prefeitura>. Acesso em: 22 abril 2015.

${ }^{10}$ BRASIL. Lei no 4.737 (1965). Código Eleitoral. Institui o código eleitoral. Brasília, DF: Congresso Nacional, 1965. Disponível em: <http://www.planalto.gov.br/ccivil_03/leis/14737.html>. Acesso em: 27 abril 2015. 
CELLA, José Renato Gaziero; ZOLET, Lucas Augusto da Silva; COPETTI, Rafael. Processo político como construção democrática: uma discussão acerca dos processos eleitorais formados por apenas uma candidatura. Revista Eletrônica Direito e Política, Programa de Pós-Graduação Stricto Sensu em Ciência Jurídica da UNIVALI, Itajaí, v.15, n.3, 30 quadrimestre de 2020. Disponível em: www.univali.br/direitoepolitica - ISSN 1980-7791

países permitem que o eleitor escolha um ou mais nomes. As cadeiras em disputa são distribuídas segundo determinada fórmula eleitoral" ${ }^{11}$.

Nos casos como o do exemplo do Município de Mato Queimado, RS, os cidadãos ficam vinculados ao modelo político singular, isto é, às restritas opções que Ihes são oportunizadas pelos dirigentes partidários que realizam o consenso para escolha de quantos e quem serão os candidatos. Ao fim, restaram-Ihes apenas três alternativas: votar no candidato único (para o cargo do Poder Executivo) ou, no caso dos vereadores, entre os candidatos originários de um acordo entre um restrito grupo dominante no cenário político partidário; votar em branco; ou anular o voto.

Destaca-se, com relação a opção de votar nulo ou em branco que, independentemente, do motivo que leva o eleitor a essa escolha, sua manifestação não será considerada para eleger ou não o candidato. Não importa que a intenção seja rejeitar o nome indicado, protestar ou demonstrar a sua indiferença com os nomes apresentados. Ou, ainda, que a motivação seja a ausência de identificação com a lista de candidatos ou, em última análise, apenas para cumprir o dever constitucional de exercício do voto. Logo, poucos votos são necessários para que o candidato seja eleito, ainda que a quase totalidade de eleitores opte por uma dessas modalidades.

No exemplo do Município de Mato Queimado/RS é possível que os cargos eletivos sejam ocupados por grupos determinados sem que seja substancialmente permitida ao cidadão a livre escolha entre ideias e interesses divergentes, planos de governo ou concepções ideológicas distintas. A indicação de apenas um nome para concorrer ao cargo de prefeito e a formação de uma coligação uniforme de ideias, isto é, sem formar uma oposição, pode comprometer ou até mesmo inviabilizar o debate entre os diversos setores da comunidade. Minorias ideológicas dificilmente não são subjugadas nessas coalizões, sendo inviabilizado seu acesso aos cargos representativos e com poderes decisórios.

Vale lembrar que a concepção moderna de Democracia surge em contraposição ao individualismo, numa perspectiva pluralista combativa, na qual os grupos

${ }^{11}$ NICOLAU, Jairo Marconi. Sistemas eleitorais. 6. Ed. Rio de Janeiro: FGV, 2012, p. 47. 
CELLA, José Renato Gaziero; ZOLET, Lucas Augusto da Silva; COPETTI, Rafael. Processo político como construção democrática: uma discussão acerca dos processos eleitorais formados por apenas uma candidatura. Revista Eletrônica Direito e Política, Programa de Pós-Graduação Stricto Sensu em Ciência Jurídica da UNIVALI, Itajaí, v.15, n.3, 30 quadrimestre de 2020. Disponível em: www.univali.br/direitoepolitica - ISSN 1980-7791

sociais, independentemente das ideologias, sobressaem-se aos indivíduos. ${ }^{12}$ Há, assim, um conteúdo substancial implícito na ideia de Democracia, porque procura-se o aperfeiçoamento da ordem social por meio da vontade coletiva.

Em contraposição aos modelos políticos singulares, a Democracia ideal e seus processos devem projetar pelo menos seis características básicas, quais sejam a participação efetiva, a igualdade de votos, o eleitorado informado ou compreensão esclarecida, o controle cidadão do programa de ações ou controle da agenda e a inclusão política. ${ }^{13}$

A característica da participação efetiva está inserida na ideia de que, antes de aceitar ou recursar uma política, os indivíduos de uma sociedade têm a oportunidade de manifestar aos demais membros as suas opiniões a respeito do tema. A igualdade de votos significa que todos os membros têm oportunidade de votar a favor ou contra determinada política, sendo que os votos têm igual valor. $^{14}$

A característica do eleitorado informado faz referência ao indivíduo esclarecido, ou seja, dentro de um período razoável de tempo, todos os membros têm a oportunidade de aprender sobre a política em discussão e acerca das possíveis políticas alternativas e suas prováveis consequências. A quarta característica é o controle cidadão do programa de ações, em que cabe tão somente aos cidadãos decidirem quais assuntos se incluem na agenda de tomadas de decisão e como serão executadas. ${ }^{15}$

Por fim, a inclusão política trata da hipótese de que cada um dos membros da sociedade tenham o direito de participar de forma igual e efetiva, conforme os critérios expostos. Logo, cada membro tem o direito de que seu voto seja computado igualmente aos demais, de receber informação pública, de participar

\footnotetext{
12 MOUFFE, Chantal. O regresso do político. Tradução de Ana Cecília Simões. Lisboa: Gradiva, 1996, p. 15.

${ }^{13}$ DAHL, Robert. La Democracia. In Encyclopaedia britannica (2004). Tradução de Silvina Floria. Disponível em: <http://sociologiapolitica.sociales.uba.ar/files/2013/09/Dahl-POstdata.pdf>. Acesso em 27 jan. 2015, p. 46.
}

${ }^{14}$ DAHL, Robert. A democracia e seus críticos. p. 171-172.

${ }^{15}$ DAHL, Robert. A democracia e seus críticos. p. 175-176. 
CELLA, José Renato Gaziero; ZOLET, Lucas Augusto da Silva; COPETTI, Rafael. Processo político como construção democrática: uma discussão acerca dos processos eleitorais formados por apenas uma candidatura. Revista Eletrônica Direito e Política, Programa de Pós-Graduação Stricto Sensu em Ciência Jurídica da UNIVALI, Itajaí, v.15, n.3, 30 quadrimestre de 2020. Disponível em: www.univali.br/direitoepolitica - ISSN 1980-7791

de forma idêntica aos demais e de exercer com a coletividade o controle do Poder Político. ${ }^{16}$

Essas características fundamentam a ideia de processo político democrático defendida na presente pesquisa justamente em contraposição ao modelo singular de processo político. Aliás, neste trabalho não se propõe um significado absoluto dos processos políticos democráticos, mas sim um conceito interpretativo capaz de possibilitar a identificação da incompatibilidade dos fundamentos da Democracia com eleições em modelos singulares. Também é por isso que os conteúdos da cidadania e diálogo democrático permanecem com sentidos amplos, uma vez que não interessa a fixação de sentidos, mas sim a possibilidade de articulação argumentativa desses elementos como condição da própria existência dos processos políticos democráticos.

A partir dessa linha de pensamento, os processos políticos democráticos estão inseridos na configuração de um novo sistema político, designado pela doutrina de Robert Dahl ${ }^{17}$ como Poliarquia (ou Democracia moderna ou Democracia representativa moderna ou, ainda, países democráticos).

Todavia, para que um sistema de governo seja classificado como uma Poliarquia se faz necessária a presença de sete instituições: funcionários eleitos, eleições livres e justas, sufrágio inclusivo, direito de concorrer a cargos eletivos, liberdade de expressão, informação alternativa e autonomia associativa. ${ }^{18}$

As referidas instituições, como ideais democráticos ou condições prévias de possibilidade de democracias, apresentam uma relação de complementariedade entre si e devem estar presentes nas realidades de países que aspiram uma constituição efetiva de regimes democráticos. No Estado Democrático de Direito é essencial a convivência dessas instituições com o pluralismo de ideias, o respeito e a tolerância aos diferentes interesses, bem como à heterogeneidade.

\footnotetext{
16 DAHL, Robert. A democracia e seus críticos. p. 176-177.

17 DAHL, Robert. A democracia e seus críticos. p. 346.

18 DAHL, Robert. A democracia e seus críticos. p. 350-351.
} 
CELLA, José Renato Gaziero; ZOLET, Lucas Augusto da Silva; COPETTI, Rafael. Processo político como construção democrática: uma discussão acerca dos processos eleitorais formados por apenas uma candidatura. Revista Eletrônica Direito e Política, Programa de Pós-Graduação Stricto Sensu em Ciência Jurídica da UNIVALI, Itajaí, v.15, n.3, 30 quadrimestre de 2020. Disponível em: www.univali.br/direitoepolitica - ISSN 1980-7791

Para Chantal Mouffe ${ }^{19}$ o "[...] universalismo não é rejeitado, mas particularizado; o que é necessário é um novo tipo de articulação entre o universal e o particular". É fundamental, assim, que seja reconhecida a diferença, o particular, o múltiplo, o heterogêneo, pois os direitos que hoje devem ser assegurados decorrerem justamente das diferenças e das peculiaridades que surgem da conflitualidade entre os indivíduos.

Nesse contexto é que as instituições democráticas devem possuir instrumentos que auxiliem na efetivação real de direitos fundamentais às pessoas. Ainda, devem garantir autonomias e liberdades, por exemplo, de expressão, de acesso à informação, as quais irão contribuir para a consolidação dos valores políticos e a compreensão das relações sociais. Logo, as liberdades possuem um valor intrínseco na medida em que permitem um efetiva "[...] oportunidade de moldar a sua vida conforme os seus próprios objetivos, preferências, gostos, valores, compromissos, convicções. A democracia protege essa liberdade" ${ }^{20}$

Desse modo, os processos democráticos hodiernos não podem ser caracterizados a partir de um modelo formal, baseado tão somente na forma como o governo é exercido ou como o modelo previsto na Constituição de determinado país. Devem ser levadas em consideração as especificidades sociais que garantam substancialmente a igualdade de condições, a soberania popular, manifestada por meio de eleições livres.

Nada obstante, nas atuais Democracias constitucionais não há que se falar tão somente no exercício do poder da maioria para legitimar uma decisão. Referido poder está limitado diante do paradigma do Estado Democrático de Direito, devendo observar tanto a forma quanto o conteúdo para o seu exercício. A realização apenas do aspecto formal da Democracia poderá gerar atitudes contrárias à própria Democracia.

Referido posicionamento é corroborado por Ferrajoli ${ }^{21}$ :

\footnotetext{
19 MOUFFE, Chantal. O regresso do político. p. 27.

20 DAHL, Robert. Sobre a democracia. Tradução de Beatriz Sidou. Brasília: Universidade de Brasília, 2001, p. 65.

21 FERRAJOLI, Luigi. Sobre la definición de "Democracia". Una discusión con Michelangelo Bovero. In Revista de teoría y filosofía del derecho, nº19. Isonomia, 2003, pp. 228-240. Disponível
} 
CELLA, José Renato Gaziero; ZOLET, Lucas Augusto da Silva; COPETTI, Rafael. Processo político como construção democrática: uma discussão acerca dos processos eleitorais formados por apenas uma candidatura. Revista Eletrônica Direito e Política, Programa de Pós-Graduação Stricto Sensu em Ciência Jurídica da UNIVALI, Itajaí, v.15, n.3, 30 quadrimestre de 2020. Disponível em: www.univali.br/direitoepolitica - ISSN 1980-7791

Para que un sistema sea democrático se requiere al menos que a la mayoría le sea sustraído el poder de suprimir el poder de la mayoría. Pero éste es un rasgo substancial, que tiene que ver con el contenido de las decisiones y que por lo tanto contradice la tesis según la cual la Democracia consistiría únicamente en un método, o sea, en las reglas procedimentales que aseguran, a través del sufragio universal y del principio de mayoría, la representatividad popular de las decisiones mismas. Rasgos substanciales, como garantía de las mismas formas y del mismo método democrático y de sus variados y complejos presupuestos, se requieren entonces como necesarios para toda definición teórica de "Democracia" dotada de adecuada capacidad explicativa. Es así como se obtiene un paradigma complejo la Democracia constitucional - que incluye, junto a la dimensión política o "forma", también una dimensión que bien podemos llamar "substancial" dado que se refiere a los contenidos o substancia de las decisiones: aquello que a cualquier mayoría le está por un lado prohibido y, por el otro, les es obligatorio decidir.

Portanto, não se deve apenas garantir o sufrágio universal, mas igualmente a livre manifestação de opinião diante das oportunidades que são postas aos cidadãos. A convivência de posições ideológicos antagônicas é salutar ao desenvolvimento do processo democrático, possibilitando que os temas sejam discutidos de forma mais ampla e levando em consideração as opiniões de todos os setores da sociedade.

No contexto dos modelos singulares de processos políticos é possível que valores democráticos possam estar restritos e comprometidos frente à ausência do debate público, havendo grande propensão de que as minorias sejam excluídas da vida política e que os problemas sociais não sejam discutidos de forma ampla e transparente. A oposição às políticas públicas apresentadas pelos candidatos ou até mesmo adotadas pelos representantes já eleitos devem ser livremente auferidas pelo povo, o qual tem o poder de discordar e rejeitá-las de forma efetiva.

Segundo Norberto Bobbio, para a afirmação da Democracia, além da participação direta ou indireta da população na tomada de decisões coletivas e da existência

em:

<http://www.cervantesvirtual.com/servlet/SirveObras/01372719724684726977680/Isonomia_10. pdf>. Aceso em: 16 nov. 2015, p. 229-230. 
CELLA, José Renato Gaziero; ZOLET, Lucas Augusto da Silva; COPETTI, Rafael. Processo político como construção democrática: uma discussão acerca dos processos eleitorais formados por apenas uma candidatura. Revista Eletrônica Direito e Política, Programa de Pós-Graduação Stricto Sensu em Ciência Jurídica da UNIVALI, Itajaí, v.15, n.3, 30 quadrimestre de 2020. Disponível em: www.univali.br/direitoepolitica - ISSN 1980-7791

de regras como a da maioria, é indispensável "[...] que aqueles que são chamados a decidir ou a eleger os que deverão decidir sejam colocados diante de alternativas reais e postos em condição de poder escolher entre uma e outra". ${ }^{22}$

O consenso, nos casos ilustrados anteriormente, tende a excluir uma forma de controle do poder público ou dificultar o poder de fiscalização da população. Ainda mais um acordo para preencher as vagas no Poder Legislativo, no qual a presença de oposicionistas contribui de forma significativa no controle das ações governamentais e na deliberação de políticas diversas para as tomadas de decisões em benefício da sociedade.

Não é recomendável, portanto, que a favor de um argumento abstrato em benefício da governabilidade se sustente que um acordo de poucos líderes político-partidários, ou que um modelo de processo político singular, é uma hipótese viável ao gerenciamento público na Democracia. É, em última análise, um perigoso espaço para arbitrariedades e abusos de poder político.

\section{PROCESSO POLÍtICO DEMOCRÁtICO COMO DESACORDO E PLURALIDADE}

Como visto, as questões que orientam as discussões da Democracia no âmbito dos processos políticos sem pluralidade de representação estão relacionadas, principalmente, à impossibilidade do efetivo diálogo democrático, bem como da diminuição da inclusão política vista como categoria de cidadania e sustentabilidade das relações sociais.

É por evidente, então, que os processos políticos que aderem a pretensão da unanimidade democrática estão baseados em uma fórmula que busca homogeneizar as pretensões e composições ideológicas de determinada comunidade. Todavia, como mencionado anteriormente, não é viável defender uma unanimidade ou consenso em todas as dimensões da sociedade.

É justamente com o desacordo, ou seja, com as diferenças e a pluralidade de opiniões que o processo político alcança uma condição potencial de atender aos

${ }^{22}$ BOBBIO, Norberto. O futuro da democracia. Tradução Marco Aurélio Nogueira. 9. Ed. São Paulo: Paz e Terra, 2000, p. 32. 
CELLA, José Renato Gaziero; ZOLET, Lucas Augusto da Silva; COPETTI, Rafael. Processo político como construção democrática: uma discussão acerca dos processos eleitorais formados por apenas uma candidatura. Revista Eletrônica Direito e Política, Programa de Pós-Graduação Stricto Sensu em Ciência Jurídica da UNIVALI, Itajaí, v.15, n.3, 30 quadrimestre de 2020. Disponível em: www.univali.br/direitoepolitica - ISSN 1980-7791

diferentes interesses e demandas sociais, porque "A Democracia encontra-se em perigo não apenas quando o consenso e a fidelidade aos valores que ela encarna são insuficientes, mas também quando a sua dinâmica combativa é travada por um aparente excesso de consenso". ${ }^{23}$

Somente nesse contexto que a política será o exercício do poder de cooperação (fiscalização) e coordenação (vigilância) dos atos públicos, convergindo para um efetivo interesse de integração social. A integração da comunidade política depende do processo democrático que, por sua vez, não se manifesta diante da insuficiência de competividade e debate público.

A partir dessa linha de pensamento, observa-se que o processo eleitoral possui uma lógica de inclusão política voltada justamente para uma hipótese da soberania da expressão dos diferentes interesses que movem determinada sociedade democrática, sobretudo com base no artigo 14 da Constituição Federal de 1988, segundo o qual "A soberania popular será exercida pelo sufrágio universal e pelo voto direto e secreto, com valor igual para todos". ${ }^{24}$

Especula-se que, em determinado espaço público, quanto maior o grau de inclusão política, maior é a compreensão da Democracia e, por conseguinte, será maior o grau também da sustentabilidade da política democrática. ${ }^{25} \mathrm{Em}$ outras palavras, significa dizer que os fundamentos da Democracia exigem o pensamento plural de interesses porque estes formam o complexo da cidadania e do diálogo democrático.

A cidadania deve ser vista como um elemento vital para a política democrática. Uma teoria democrática moderna, segundo Mouffe $^{26}$, tem de possibilitar que as

\footnotetext{
${ }^{23}$ MOUFFE, Chantal. 0 regresso do político. p. 17.

${ }^{24}$ BRASIL. Constituição (1988). Constituição da república federativa do brasil. Brasília, DF: Senado, $1988 . \quad$ Disponível em: <http://www.planalto.gov.br/ccivil_03/constituicao/ConstituicaoCompilado.htm> Acesso em: 28 abril 2015.

25 Para Ignacy Sachs o critério de sustentabilidade política significa o desenvolvimento de uma Democracia definida em termos de um nível razoável de coesão social, da plena proteção dos direitos humanos e do desenvolvimento da capacidade do Estado para implementar um projeto político nacional. SACHS, Ignacy. Caminhos para o desenvolvimento sustentável. Tradução de José Lins Albuquerque Filho. Rio de Janeiro: Garamond, 2009, p. 87.
}

${ }^{26}$ MOUFFE, Chantal. O regresso do político. p. 18. 
CELLA, José Renato Gaziero; ZOLET, Lucas Augusto da Silva; COPETTI, Rafael. Processo político como construção democrática: uma discussão acerca dos processos eleitorais formados por apenas uma candidatura. Revista Eletrônica Direito e Política, Programa de Pós-Graduação Stricto Sensu em Ciência Jurídica da UNIVALI, Itajaí, v.15, n.3, 30 quadrimestre de 2020. Disponível em: www.univali.br/direitoepolitica - ISSN 1980-7791

concepções divergentes de cidadania estejam presentes no processo político democrático e formem a identidade coletiva dos cidadãos.

Esses argumentos se mostram relevantes porque uma concepção política que se dedique a analisar as sociedades contemporâneas deve considerar que estas sofrem um processo de redefinição das suas identidades coletivas e experimentam continuamente o estabelecimento de novas fronteiras políticas. Logo, a dimensão do debate público e a consideração do antagonismo de interesses devem ser respeitadas como questões fundamentais para a formação dos processos eleitorais democráticos.

Esse respeito também faz parte da nova constituição das identidades coletivas que, claramente, são as próprias expectativas reais inseridas nas práticas democráticas, por exemplo, a disputa eleitoral. Portanto, as identidades coletivas como alternativas democráticas moldam uma espécie de pluralismo de interesses que, por sua vez, é o constitutivo de um regime democrático. ${ }^{27}$

A Democracia e seus processos políticos, assim, faz parte do complexo do pluralismo, ou seja, devem conjugar diferentes interesses observando nem consenso nem dissenso absoluto. Segundo Bobbio existe uma relação necessária entre Democracia e desacordo, porque "[...] uma vez admitido que Democracia significa consenso real e não fictício, a única possibilidade que temos de verificar se o consenso é real é verificando o seu contrário". ${ }^{28}$

Nota-se que, quando o processo eleitoral incorpora o princípio do pluralismo, há perfeita constituição de uma hegemonia de matriz democrática. Esse é verdadeiramente, também, um esforço coletivo que, segundo Mouffe ${ }^{29}$, passa pela multiplicação do diálogo democrático, o qual é institucionalizado nas relações sociais.

Do mesmo modo que o complexo da cidadania, o diálogo democrático se faz determinante aos processos políticos eleitorais. A questão, por conseguinte, está

\footnotetext{
27 MOUFFE, Chantal. 0 regresso do político. p. 57.

${ }^{28}$ BOBBIO, Norberto. 0 futuro da democracia. p. 75.

${ }^{29}$ MOUFFE, Chantal. O regresso do político. p. 33.
} 
CELLA, José Renato Gaziero; ZOLET, Lucas Augusto da Silva; COPETTI, Rafael. Processo político como construção democrática: uma discussão acerca dos processos eleitorais formados por apenas uma candidatura. Revista Eletrônica Direito e Política, Programa de Pós-Graduação Stricto Sensu em Ciência Jurídica da UNIVALI, Itajaí, v.15, n.3, 30 quadrimestre de 2020. Disponível em: www.univali.br/direitoepolitica - ISSN 1980-7791

fundada na relação do Direito, como garantidor de liberdades, com a Democracia como modelo político de promoção do debate público.

Essa relação entre Direito e Democracia é um aspecto relevante para Jeremy Waldron $^{30}$, posto que, segundo esse autor, no centro das discussões do Estado Democrático de Direito existe sempre um elemento presente, qual seja o desacordo. Discordar sobre questões da vida social é o próprio fundamento da Democracia e, em meio aos temas de discordância, a Política, desde a origem nos processos eleitorais, é formatada com força nos desacordos coletivos que, por conseguinte, na relação com o Direito condicionam novas legislações. Logo, o desacordo como fonte do diálogo democrático é um elemento determinante para fins de novas posições dos direitos e políticas públicas.

Nesse sentido, observa-se que o diálogo democrático é uma força política inerente à Democracia. Isso ocorre, primeiro, porque a legitimidade do poder político democrático depende do debate público e, segundo, porque o desacordo entre os indivíduos quanto aos seus objetivos é uma das circunstâncias da Política. Estima-se, portanto, que o modelo político singular não efetiva uma ampla condição de debate público.

Aliás, afirma-se que o desacordo é uma circunstância Política especialmente porque, segundo Waldron, a "[...] nossa base comum para a ação em questões de justiça tem de ser forjada no calor das nossas discordâncias, não fundamentada na suposição de um consenso sereno que existe apenas como ideal". ${ }^{31}$

Portanto, a cidadania e o diálogo democrático são dois elementos que concedem força ao argumento segundo o qual os processos políticos eleitorais devem ser construídos com o maior número de candidatos possíveis. Logo, uma candidatura isolada não é capaz de fomentar a cidadania como pluralidade de interesses, muito menos um efetivo diálogo democrático.

\footnotetext{
30 WALDRON, Jeremy. A dignidade da legislação. Tradução de Luís Carlos Borges. São Paulo: Martins Fontes, 2003, p. 43.

${ }^{31}$ WALDRON, Jeremy. A dignidade da legislação. p. 189.
} 
CELLA, José Renato Gaziero; ZOLET, Lucas Augusto da Silva; COPETTI, Rafael. Processo político como construção democrática: uma discussão acerca dos processos eleitorais formados por apenas uma candidatura. Revista Eletrônica Direito e Política, Programa de Pós-Graduação Stricto Sensu em Ciência Jurídica da UNIVALI, Itajaí, v.15, n.3, 30 quadrimestre de 2020. Disponível em: www.univali.br/direitoepolitica - ISSN 1980-7791

Essa questão é relevante porque o processo eleitoral deve ser um processo democrático includente, ou seja, um processo respeitoso da própria Democracia. Esse respeito ocorre em duas dimensões. Primeiro, porque considera a realidade das diferenças de opinião quanto às principais questões da vida em sociedade. Segundo, porque a multiplicidade de candidatos pressupõe o não consenso, sobretudo, porque esse é um ideal da Democracia que permite o direito de escolha e o desenvolvimento da liberdade de proteção dos próprios interesses pessoais. $^{32}$

Os processos eleitorais, assim, são democraticamente sustentados quando respeitam e possibilitam o efetivo exercício das duas dimensões referidas. A consideração dessas dimensões é o caminho para um processo plenamente democrático porque estabelece uma nova fronteira política da Democracia. $\mathrm{Na}$ concepção de Dworkin ${ }^{33}$, os cidadãos têm como uma questão de princípio que seus interesses sejam considerados, ou seja, o Estado Democrático de Direito é um espaço político plural que confirma as concepções de Justiça Social a partir da proteção dos direitos individuais.

Nesse viés, a Democracia é vista como um regime e também um processo político sem igual para a tomada de decisões. Segundo Dahl ${ }^{34}$, a Democracia forma uma enorme teia multidimensional, construída de fios interligados que possuem distintos graus de elasticidade. Logo, essa teia é grande o suficiente para exigir mais que meramente um modelo político singular.

Esse conceito de teia democrática pode ser relacionado às diferentes orientações argumentativas da sociedade, sendo que enquanto algumas partes da teia são compostas de fios rigidamente ligados (aspectos relacionados aos direitos que constituem o processo democrático), outras partes são ligadas de maneira mais solta e algumas ligações são extremamente tênues (aspectos de deliberação relativamente abstrata, que embora não constituam o processo democrático são

\footnotetext{
32 DAHL, Robert. A democracia e seus críticos. p. 495.

33 DWORKIN, Ronald. Uma questão de princípio. Tradução Luís Carlos Borges. 2. Ed. São Paulo: Martins Fontes, 2005, p. 38-39.

${ }^{34} \mathrm{DAHL}$, Robert. A democracia e seus críticos. p. 9.
} 
CELLA, José Renato Gaziero; ZOLET, Lucas Augusto da Silva; COPETTI, Rafael. Processo político como construção democrática: uma discussão acerca dos processos eleitorais formados por apenas uma candidatura. Revista Eletrônica Direito e Política, Programa de Pós-Graduação Stricto Sensu em Ciência Jurídica da UNIVALI, Itajaí, v.15, n.3, 30 quadrimestre de 2020. Disponível em: www.univali.br/direitoepolitica - ISSN 1980-7791

condições necessárias para sua legitimidade, por exemplo, conteúdos da liberdade e igualdade). ${ }^{35}$

Logo, as formações centrais dos processos políticos democráticos exigem uma pluralidade de representações, porque "A sociedade real, subjacente aos governos democráticos, é pluralista". ${ }^{36}$ Segue-se, portanto, que esse fundamento não está presente em pleitos eleitorais formados apenas por uma candidatura.

Reconhece-se, todavia, que a concretização deste pressuposto democrático surge, primordialmente, da articulação eleitoral e da vontade individual de participação política. O papel dos indivíduos na sua especificidade também é relevante para a garantia de posição política da Democracia nos processos eleitorais.

Com isso é possível frisar que a falta de oposições é um problema para a Democracia na medida em que a restrição ou inexistência de competividade nos pleitos eleitorais fragiliza a fiscalização e a vigilância dos atos do Poder Político. Do mesmo modo, o argumento do consenso deve ser refutado, porque "[...] o consenso unânime é impossível e que lá onde se diz que existe é um consenso organizado, manipulado, manobrado e portanto fictício". ${ }^{37}$

Na linha dos argumentos expostos, nota-se, em Estados ou Nações onde não há um efetivo exercício da competição política partidária, a existência de uma consistente hipótese de que ali estejam estabelecidos regimes políticos violadores de direitos fundamentais ou, pelo menos, da completa inoperância destes direitos. Exemplos dessa condição podem ser encontrados em países ou comunidades não-livres como ditaduras militares, monarquias repressivas e governos com partidos dominantes. ${ }^{38}$

\footnotetext{
${ }^{35}$ WALDRON, Jeremy. Law and disagreement. New York: Oxford University Press, 2004, p. 283.

${ }^{36}$ BOBBIO, Norberto. 0 futuro da democracia. p. 36.

${ }^{37}$ BOBBIO, Norberto. 0 futuro da democracia. p. 74.

38 Segundo Gene Sharp, desde 2008 mais de $30 \%$ da população mundial vivia em países nãolivres, ou seja, territórios com extremas restrições aos direitos políticos e liberdades civis. Estes países geralmente são governados por ditaduras militares (como na antiga Birmânia), monarquias tradicionais repressivas (como na Arábia Saudita) e partidos políticos dominantes (como na Coréia do Norte). SHARP, Gene. Da ditadura à democracia: uma estrutura conceitual para a libertação. Tradução de José A.S. Filardo. Boston: The Albert Einstein Institution, 2010, p.
} 
CELLA, José Renato Gaziero; ZOLET, Lucas Augusto da Silva; COPETTI, Rafael. Processo político como construção democrática: uma discussão acerca dos processos eleitorais formados por apenas uma candidatura. Revista Eletrônica Direito e Política, Programa de Pós-Graduação Stricto Sensu em Ciência Jurídica da UNIVALI, Itajaí, v.15, n.3, 30 quadrimestre de 2020. Disponível em: www.univali.br/direitoepolitica - ISSN 1980-7791

São esses os principais aspectos que concedem fundamento à necessidade da promoção dos modelos políticos ambivalentes que favoreçam o diálogo democrático, a inclusão política e a promoção dos direitos fundamentais. Sem dúvida esses elementos interessam a qualquer Estado Democrático de Direito.

Por fim, é possível observar no quadro ilustrativo apresentado abaixo, de autoria própria, algumas das características objetos de argumentação da presente pesquisa. As características apresentadas no quadro demonstram elementos característicos de significativas diferenças entre o processo político democrático e o modelo político singular:

\section{Quadro 1 - Comparativo entre dois modelos de processos políticos eleitorais}

\begin{tabular}{|c|c|}
\hline Modelos & $\begin{array}{c}\text { Características } \\
\text { Processo Político } \\
\text { Democrático }\end{array}$ \\
$\begin{array}{c}\text { Ampla discussão pública mediante debates } \\
\text { eleitorais; } \\
\text { Funda-se na consideração plural de interesses; } \\
\text { Maior poder de fiscalização e vigilância dos atos } \\
\text { públicos; }\end{array}$ \\
$\begin{array}{c}\text { Há pressupostos de oposição política. } \\
\text { Modelo Político } \\
\text { Singular }\end{array}$ & $\begin{array}{c}\text { Debate é restrito no âmbito dos partidos } \\
\text { policos; } \\
\text { Lunda-se no acordo entre partidos; } \\
\text { Menor poder de fiscalização e vigilância dos } \\
\text { atos públicos; }\end{array}$ \\
& \begin{tabular}{c} 
Não há pressupostos de oposição política. \\
\hline
\end{tabular} \\
\hline
\end{tabular}

Fonte: Autoria própria.

Portanto, com base nos argumentos expostos, é possível afirmar que processos eleitorais que não reúnam as características, por exemplo, da ampla discussão pública, da legitimação pelo não consenso, da consideração plural de interesses, bem como da existência de oposição política, não estão efetivamente alinhados com os pressupostos mais básicos da Democracia. 
CELLA, José Renato Gaziero; ZOLET, Lucas Augusto da Silva; COPETTI, Rafael. Processo político como construção democrática: uma discussão acerca dos processos eleitorais formados por apenas uma candidatura. Revista Eletrônica Direito e Política, Programa de Pós-Graduação Stricto Sensu em Ciência Jurídica da UNIVALI, Itajaí, v.15, n.3, 30 quadrimestre de 2020. Disponível em: www.univali.br/direitoepolitica - ISSN 1980-7791

Nesse sentido, a falta da consideração dos pressupostos democráticos, bem como das características acima mencionadas, faz do processo político singular um modelo insuficiente. Significa dizer também que os modelos singulares de processo político restringem e não respeitam as concepções democráticas vinculadas aos fundamentos da Democracia e do Estado Democrático de Direito.

\section{CONSIDERAÇÕES FINAIS}

O problema dos processos políticos eleitorais formados por apenas uma candidatura, sobretudo no contexto do Estado Democrático de Direito, revela a necessidade da consideração dos pressupostos democráticos na formação dos processos eleitorais. Essa significação permite que elementos fundamentais da Democracia, por exemplo o diálogo democrático, sejam possivelmente efetivados para além dos pequenos grupos detentores do poder político.

A pesquisa das características fundamentais dos processos políticos, conceitos oriundos especialmente da doutrina de Robert Dahl, permitiu a compreensão teórica de que os modelos políticos singulares não respeitam efetivamente as características mais básicas da Democracia e do Estado Democrático de Direito, por exemplo, a necessária consideração plural dos interesses.

Do mesmo modo, o presente estudo possibilitou identificar que os aspectos constitutivos dos processos políticos democráticos, por exemplo a existência de oposição política, fundamentam uma das condições da Democracia, qual seja o desacordo público como elemento essencial da construção política democrática.

Essa construção da Democracia, identificada ao elemento do desacordo como circunstância da Política contemporânea, funda-se em processos políticos democráticos, posto que são esses modelos os que são capazes de melhor promover o desenvolvimento humano. O modelo político singular agarra-se ao consenso como espécie de legitimidade, todavia uma sociedade plural está fundada no desacordo como próprio fundamento de integridade política.

As práticas de desenvolvimento das sociedades democráticas precisam estar pautadas em alternativas que considerem a realidade das diferenças de opinião quanto às principais questões da vida social, bem como na promoção das 
CELLA, José Renato Gaziero; ZOLET, Lucas Augusto da Silva; COPETTI, Rafael. Processo político como construção democrática: uma discussão acerca dos processos eleitorais formados por apenas uma candidatura. Revista Eletrônica Direito e Política, Programa de Pós-Graduação Stricto Sensu em Ciência Jurídica da UNIVALI, Itajaí, v.15, n.3, 30 quadrimestre de 2020. Disponível em: www.univali.br/direitoepolitica - ISSN 1980-7791

liberdades e interesses pessoais. Logo, uma ideia de consenso como fundamento do modelo político singular pode significar um regime de Democracia restrita, com baixos níveis de cidadania.

Nessa linha de pensamento, a presente pesquisa, orientada pela hipótese segundo a qual os modelos políticos singulares não respeitam efetivamente os pressupostos democráticos mais básicos, sustentada por elementos teóricos acerca do desenvolvimento da Democracia na contemporaneidade e sua relação conflituosa com a formação dos processos políticos eleitorais, demonstrou que, no âmbito dos modelos singulares de processo político, há uma relação problemática quanto à promoção das características fundamentais dos processos democráticos. Essa relação está inserida, sobretudo, no âmbito das características da participação efetiva, do eleitorado informado, do controle cidadão do programa de ações e da inclusão política.

Isso porque as características fundamentais dos processos políticos projetam uma efetiva participação dos indivíduos na vida pública. Um exercício contínuo de fiscalização dos atos do governo que pode afetar em concreto a apreciação da condução dos interesses da coletividade. Legítimo, portanto, que processos políticos eleitorais estejam alinhados com as características fundamentais na maior medida possível.

Sistemas eleitorais representativos, nesse contexto, devem buscar assegurar a possibilidade de manifestação da maior amplitude possível dos diferentes núcleos sociais. Como analisado, a efetivação do ideal dos processos políticos democráticos deve passar por um debate que leve em consideração as diferentes concepções ideológicas que coexistem. E referido anseio somente poderá ser realizado no momento em que também as minorias tenham possibilidade de se expressar e escolher de forma real e não apenas formal.

Além disso, o estudo do conceito da Poliarquia e suas relações com as instituições democráticas permitiu identificar que os modelos políticos singulares pouco se aproximam do ideal democrático. Por exemplo, os ideais de sufrágio inclusivo, direito de concorrer a cargos eletivos, liberdade de expressão, informação alternativa e autonomia associativa, parecem distantes da forma original que se estabelecem processos políticos com apenas uma candidatura. 
CELLA, José Renato Gaziero; ZOLET, Lucas Augusto da Silva; COPETTI, Rafael. Processo político como construção democrática: uma discussão acerca dos processos eleitorais formados por apenas uma candidatura. Revista Eletrônica Direito e Política, Programa de Pós-Graduação Stricto Sensu em Ciência Jurídica da UNIVALI, Itajaí, v.15, n.3, 30 quadrimestre de 2020. Disponível em: www.univali.br/direitoepolitica - ISSN 1980-7791

Os processos políticos democráticos devem conter instrumentos que auxiliem na efetivação dos direitos fundamentais e não projetar uma comunidade em meio à ausência de identidades. Um processo que projete a garantia das autonomias e liberdades certamente irá contribuir para a consolidação dos fundamentos da Democracia e da compreensão das relações sociais.

O presente estudo permitiu pressupor, também, que em modelos de processos políticos com uma única candidatura não há um efetivo exercício da competição política partidária. Essa afirmação compreende que muitos interesses sociais podem ser desconsiderados na medida em que os projetos do governo estejam vinculados a uma minoria.

De fato, o problema da concentração do poder político está fundado na semelhança encontrada com alguns países não-livres como ditaduras militares, monarquias repressivas e governos com partidos dominantes. Com isso, os modelos políticos singulares, na medida em que alcancem maiores espaços e dimensões político-estruturais, podem significar um perigoso retrocesso em relação ao processo de aprimoramento democrático.

Ademais, a hegemonia política de pequenos grupos e a ausência de uma perspectiva real de participação nas tomadas de decisões podem acarretar uma temerária ociosidade política, no sentido de que aqueles que estão excluídos da tomada de decisões se tornem cada vez menos proativos.

O caminho para o desenvolvimento de cenários inclusivos ou politicamente sustentados no âmbito da sociedade contemporânea certamente não será traçado por meio dos processos políticos eleitorais formados por apenas uma candidatura. Os novos desafios que se apresentam à sociedade exigem mais que consenso, exigem verdadeiramente mais diálogo, cidadania e inclusão política.

A convivência com posicionamentos divergentes e o debate público serão elementos que contribuirão para a construção e estabilização desse modelo sustentável de Democracias políticas, fundamentadas nas premissas já discutidas. A divergência deve ser entendida como processo imprescindível para - aperfeiçoamento dos sistemas vigentes em cada uma das realidades democráticas já existentes. Portanto, a validação jurídica de candidaturas únicas 
CELLA, José Renato Gaziero; ZOLET, Lucas Augusto da Silva; COPETTI, Rafael. Processo político como construção democrática: uma discussão acerca dos processos eleitorais formados por apenas uma candidatura. Revista Eletrônica Direito e Política, Programa de Pós-Graduação Stricto Sensu em Ciência Jurídica da UNIVALI, Itajaí, v.15, n.3, 30 quadrimestre de 2020. Disponível em: www.univali.br/direitoepolitica - ISSN 1980-7791

e de resultados eleitorais provenientes desse tipo de candidatura são temas que clamam por uma maior discussão.

\section{REFERÊNCIAS DAS FONTES CITADAS}

AGÊNCIA BRASIL. Município do noroeste gaúcho nunca teve disputa eleitoral para prefeitura. Brasília: Empresa Brasil de Comunicação, 2012a. Disponível em: <http://memoria.ebc.com.br/agenciabrasil/noticia/2012-0726/municipio-do-noroeste-gaucho-nunca-teve-disputa-eleitoral-para-prefeitura> . Acesso em: 22 abril 2015.

AGÊNCIA BRASIL. Em 106 municípios, apenas um candidato disputará a prefeitura. Brasília: Empresa Brasil de Comunicação, 2012b. Disponível em: <http://memoria.ebc.com.br/agenciabrasil/noticia/2012-07-26/em-106municipios-apenas-um-candidato-disputara-prefeitura>. Acesso em: 22 abril 2015.

ALEXY, Robert. Teoria discursiva do direito. Tradução Alexandre Travessoni Gomes Trivisonno. Rio de Janeiro: Forense Universitária, 2014.

BOBBIO, Norberto. O futuro da democracia. Tradução Marco Aurélio Nogueira. 9. Ed. São Paulo: Paz e Terra, 2000.

BRASIL. Constituição (1988). Constituição da república federativa do brasil. Brasília, DF: Senado, 1988. Disponível em: <http://www.planalto.gov.br/ccivil_03/constituicao/ ConstituicaoCompilado.htm> Acesso em: 28 abril 2015.

BRASIL. Lei no 9.504 (1997). Lei no 9.504. Estabelece normas para as eleições. Brasília, DF: Presidência da República, 1997. Disponível em:

http://www.planalto.gov.br/ccivil_03

/leis/l9504.html. Acesso em: 28 abril 2015.

BRASIL. Lei no 4.737 (1965). Código eleitoral. Institui o código eleitoral. Brasília, DF: Congresso Nacional, 1965. Disponível em:

http://www.planalto.gov.br/ccivil_03/

leis/14737.html. Acesso em: 27 abril 2015.

DAHL, Robert. A democracia e seus críticos. Tradução Patrícia de Freitas Ribeiro. São Paulo: Martins Fontes, 2012.

DAHL, Robert. La Democracia. In Encyclopaedia britannica (2004). Tradução de Silvina Floria. Disponível em:

<http://sociologiapolitica.sociales.uba.ar/files/2013/09/Dahl-POstdata.pdf>. Acesso em 27 jan. 2015.

DAHL, Robert . Sobre a democracia. Tradução de Beatriz Sidou. Brasília: Universidade de Brasília, 2001. 
CELLA, José Renato Gaziero; ZOLET, Lucas Augusto da Silva; COPETTI, Rafael. Processo político como construção democrática: uma discussão acerca dos processos eleitorais formados por apenas uma candidatura. Revista Eletrônica Direito e Política, Programa de Pós-Graduação Stricto Sensu em Ciência Jurídica da UNIVALI, Itajaí, v.15, n.3, 30 quadrimestre de 2020. Disponível em: www.univali.br/direitoepolitica - ISSN 1980-7791

DWORKIN, Ronald. Uma questão de princípio. Tradução Luís Carlos Borges. 2. Ed. São Paulo: Martins Fontes, 2005.

FERRAJOLI, Luigi. Sobre la definición de "Democracia". Una discusión con Michelangelo Bovero. In Revista de teoría y filosofía del derecho, $\mathrm{n}^{\circ} 19$. Isonomia, 2003, pp. 228-240. Disponível em:

http://www.cervantesvirtual.com/servlet/SirveObras/0137271972468

4726977680/Isonomia_10.pdf. Aceso em: 16 nov. 2015.

MOUFFE, Chantal. O regresso do político. Tradução de Ana Cecília Simões. Lisboa: Gradiva, 1996.

NICOLAU, Jairo Marconi. Sistemas eleitorais. 6. Ed. Rio de Janeiro: FGV, 2012.

SACHS, Ignacy. Caminhos para o desenvolvimento sustentável. Tradução de José Lins Albuquerque Filho. Rio de Janeiro: Garamond, 2009.

SHARP, Gene. Da ditadura à democracia: uma estrutura conceitual para a libertação. Tradução de José A.S. Filardo. Boston: The Albert Einstein Institution, 2010.

WALDRON, Jeremy. A dignidade da legislação. Tradução de Luís Carlos Borges. São Paulo: Martins Fontes, 2003.

WALDRON, Jeremy. Law and disagreement. New York: Oxford University Press, 2004. 